НАУКОВИЙ ВІСНИК

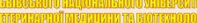

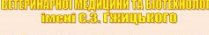

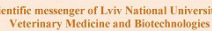
Thes nown 19 W (2)

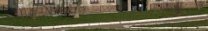
ЕРЯ: ХАРЧОВІ ТЕХНОЛОГО TOM 22 № 94 2020

\section{Науковий вісник Яьвівського національного університету} ветеринарної медицини та біотехнодогій імені С.3. Гжицького. Серія: Харчові технологіі

\author{
Scientific Messenger of Lviv National University \\ of Veterinary Medicine and Biotechnologies.
}

Series: Food Technologies

UDC 637.1

\title{
Development of beverage technology for athletes with the addition of whey proteins
}

O. Krasulya

National University of Food Technologies, Kyiv, Ukraine

Article info

Received 09.09.2020

Received in revised form 08.10 .2020

Accepted 09.10.2020

National University of Food Technologies.

Volodymyrska Str., 68 ,

Kyiv, 01033, Ukraine.

Tel.: +38-097-766-01-41

E-mail: olena_krasulya@ukr.net
Krasulya, O. (2020). Development of beverage technology for athletes with the addition of whey proteins. Scientific Messenger of Lviv National University of Veterinary Medicine and Biotechnologies. Series: Food Technologies, 22(94), 61-65. doi: 10.32718/nvlvet-f9412

The article substantiates the relevance of developing a new drink technology for sports nutrition. The combination of milk base has an obvious positive effect on the body and enrichment with the necessary plant components. According to the formula of balanced nutrition of athletes engaged in strength sports, the daily amount of necessary macronutrients was calculated. The aim of the work was to develop a milk drink with nutrients. Their content in a portion of $500 \mathrm{~g}$ will cover the daily requirement by more than $10 \%$. Taking into account theoretical research, the component composition of the drink for athletes is substantiated. The expediency of adding whey protein concentrate obtained by ultrafiltration has been proved. According to the results of experimental studies of the dynamic viscosity index, a rational amount and type of carbohydrate component in the beverage has been established. With the addition of maltodextrin in the amount of $8 \%$, a viscous-fluid consistency of the model sample is observed. The recommended limit on the amount of carbohydrates in beverages for athletes, namely an average of $10 \ldots 12 \%$, taking into account the lactose content in milk-based about $4.0 \ldots 4.5 \%$. The addition of soybean oil to the composition of the drink recipe for athletes is justified. A rational amount of lecithin emulsifier has been established to ensure the stability of the emulsion of the finished product. The composition of the milk drink recipe for athletes is given, which additionally includes a multivitamin premix, creatine monohydrate, dry extract of safflower leaflet, flavoring. The calculation of the nutritional and energy value of the developed drink was performed and the assessment of the satisfaction of the daily requirement for minerals and vitamins when drinking the drink in the amount of $500 \mathrm{~g}$ (1 serving) was performed. Consumption of the developed drink by the athlete who is engaged in power sports, in the amount of $500 \mathrm{~g}$ per day will provide the body with the necessary nutrients by more than $10 \%$.

Key words: milk drink, whey proteins, sports nutrition, technology.

\section{Розробка технології напою для спортсменів 3 додаванням сироваткових білків молока}

\author{
О. О. Красуля
}

Національний університет харчових технологій, м. Київ, Украӥна

В статті обтрунтовано актуальність вироблення нової технології напою для спортивного харчування. Доведено, що поєднання молочної основи з ї̈ очевидним позитивним впливом на організм і збагачення необхідними рослинними складовими, які відповідають потребам організму в умовах підвищеної фізичної активності, забезпечать сукупний двосторонній ефект. За формулою збалансованого харчування спортсменів, які займаються силовими видами спорту, розраховано добову кількість необхідних макронутрієнтів. Метою роботи було розробити молочний напій зі складом нутрієнтів, вміст яких в пориії 500 г дозволить покрити добову потребу більш ніж на $10 \%$ \% 3 урахуванням теоретичних досліджень, обтрунтовано компонентний склад напою для спортсменів. Доведено доиільність додавання концентрату сироваткового білка, отриманого ультрафільтрацією. За результатами експериментальних досліджень показника динамічної в'язкості встановлено раціональну кількість та вид вуглеводного компонента в напої. Так, з додаванням мальтодекстрину в кількості 8 \% спостерігається в'язко-текуча консистенція модельного зразку. Крім иього, виконується рекомендоване обмеження за кількістю вуглеводів в напоях для спортсменів, а саме в середньому $10 \ldots 12 \% 3$ 
урахуванням вмісту лактози в молочній основі 4,0...4,5\%. Обтрунтовано додавання соєвої олї до складу рецептури напою. Встановлено рачіональну кількість емульгатора лецитину для забезпечення стійкості емульсії готового продукту. Наведено склад рецептури молочного напою для спортсменів, в який додатково входять полівітамінний премікс, креатину моногідрат, сухий екстракт левзеї сафлоровидної, ароматизатор. Виконано розрахунок харчової та енергетичної цінності розробленого напою $i$ проведена очінка задоволення добової потреби в мінеральних речовинах $і$ вітамінах при вживанні напою в кількості 500 г (1 порція). Встановлено, шуо споживання розробленого напою спортсменом, який займається силовими видами спорту, в кількості 500 г на добу забезпечить організм необхідними поживними речовинами більше ніж на $10 \%$.

Ключові слова: молочний напій, сироваткові білки, спортивне харчування, технологія.

\section{Вступ}

У сучасній системі спортивної підготовки харчування розглядається як один з провідних факторів, що зумовлюють високу результативність спортсменів за рахунок стабільної працездатності та ефективного протікання відновлювальних процесів при напруженій м'язовій діяльності (Latkov et al., 2018).

Актуальність розроблення напоїв для спортивного харчування та попит на ці продукти постійно зростає як в Україні, так і за кордоном. Це пов'язано з популяризацією активного способу життя та постійним зростанням кількості як чоловічого, так і жіночого населення, яке постійно займається спортом (Babich et al., 2017).

За даними інформаційно-аналітичної компанії "Fitness Connect UA", в Україні споживачами фітнеспослуг за 2019 р. було 1,2 млн людей, або 2,9 \%. Річний обіг ринку фітнес-послуг України становить $\$ 266,6$ млн. Міжнародний звіт European Health\&Fitness Market показав, що фітнесом у Європі сьогодні займається 62,2 млн громадян, у тому числі 1,2 млн українців.

Сучасний український ринок харчових продуктів для спортсменів представлений переважно імпортними продуктами таких торгових марок, як “Optimum Nutrition" (США), "BSN" (Bio-Engineered Supplements and Nutrition, CШA), Ultimate Nutrition (СШA), Scitec Nutrition (США), Biotech USA (Угорщина) та ін. Аналізуючи існуючий асортимент харчових продуктів для спортсменів, варто зазначити, що вони представлені здебільшого у вигляді гейнерів, білкових ізолятів, енергетиків, амінокислот, креатину, L-карнітину, оксиду азоту, концентратів біологічно активних речовин для приготування коктейлів і майже зовсім не представлені у вигляді збагачених, але традиційних харчових продуктів (Badau et al., 2018; Sorrenti et al., 2019). Виняток становлять напої, асортимент яких швидко розширюється, і кондитерські вироби у вигляді шоколадних батончиків білкової, вуглеводної та білково-вуглеводної спрямованості (Rudavs'ka et al., 2002; Kalinina et al., 2018).

Відомо про технології вуглеводно-білкового кисломолочних напоїв (Trofimov, 2016; Zabodalova et al., 2019; Zakharova et al., 2019) з використанням заквашувальних культур та пробіотиків. Загалом асортимент білкових концентратів для коктейлів представлено переважно збалансованими сумішами тваринних або тваринних і рослинних білків (рослинних не більше 40 \%). Трапляється включення до протеїнових сумішей основних вітамінів і солей (Rudavska et al., 2002).
Основними вимогами при розробленні продуктів спортивного харчування є: продукти повинні вмістити максимальний набір необхідних нутрієнтів; потрібно врахувати інтереси та очікування споживачів; бути зручними у споживанні; допомагати вирішенню певного тренувального завдання або для корекції певної проблеми харчування; бути розробленими з урахуванням виду спорту, тренувально-змагального періоду, статі, віку, професійного стажу тощо (Latkov et al., 2018).

Розроблення спеціалізованих харчових продуктів, що поповнюватимуть потреби організму спортсмена в необхідних речовинах, затрачених при фізичних навантаженнях, які забезпечують підтримку імунної системи, запобігаючи стресовому стану, дозволять вирішити ці завдання.

\section{Матеріал і методи досліджень}

Розроблення технології напоїв для спортсменів 3 додаванням сироваткових білків молока проводили 3 використанням органолептичних, фізико-хімічних, мікробіологічних методів аналізу. Під час дослідів використовували стандартні та загальновідомі методи дослідження, що забезпечують виконання поставлених завдань.

Об'єкт досліджень: молоко знежирене (ДСТУ 3662:2018), концентрат сироватковий білковий “КСБУФ 65" (ТУ У 15.5-35293993-002:2011), мальтодекстрин (ТУ 9189-010-27291178-2010), вівсяне борошно (ТУ У 15.6-13929625-001:2011), олія соєва (ТУ У 10.9-22593940-002:2012), нормалізовані суміші, дослідні зразки молочних напоїв на різних стадіях виробництва.

Формула збалансованого харчування для середньостатистичної дорослої людини складає співвідношення білків:жирів:вуглеводів як 1:(0,8-1):4, або 1112 \% від загальної калорійності добового раціону.

Масове співвідношення нутрієнтів в раціоні харчування спортсменів, що займаються різними видами спорту, відрізняються. Очевидно, потрібно проектувати напої $з$ компонентним складом, що відповідає нормам оптимального споживання нутрієнтів спортсменом, який займається конкретним видом спорту. В даній роботі планується розробити напій для спортсменів, які займаються силовим і швидкісно-силовим видами спорту. Згідно $з$ літературними даними, показник добової потреби для таких спортсменів має становити (на 1 кг маси тіла): білків - 2,9 г, жирів - 2,0 г, вуглеводів - 11,8 г, калорійність - 77 кКал.

Для проектування напою візьмемо масу тіла спортсмена 80 кг. Отже, при перерахунку на добу він має споживати таку кількість нутрієнтів: білків: 
$2,9 \cdot 80=232$ г; жирів: $2,0 \cdot 80=160$ г; вуглеводів: $11,8 \cdot 80=944$ г.

Метою роботи є розроблення молочного напою зі складом нутрієнтів, вміст яких в порції 500 мг дозволяє покрити добову потребу більш ніж на $10 \%$.

\section{Результати та їх обговорення}

На формування структури продукту суттєвий вплив мають спеціально підібрані інгредієнти молочного і немолочного походження, що сприяють підвищенню харчової та біологічної цінності продукту. Додавання КСБ-УФ 65 і мальтодекстрину дозволить надати молочному напою необхідної в'язкості та кон- систенції, що важливо для надання продукту поліпшених органолептичних властивостей та повноти смаку.

3 метою визначення оптимальної концентрації та виду вуглеводного компонента досліджували вплив мальтодекстрину та вівсяного борошна на властивості молочної основи: органолептичні та фізико-хімічні. Для дослідження готувалися зразки на основі знежиреного молока 3 концентрацією вуглеводів, \%: 3, 5, 8, 11. Контроль - без додавання мальтодекстрину. Вплив виду та кількості вуглеводного компоненту в молочній суміші на показник динамічної в'язкості наведено на рис. 1.

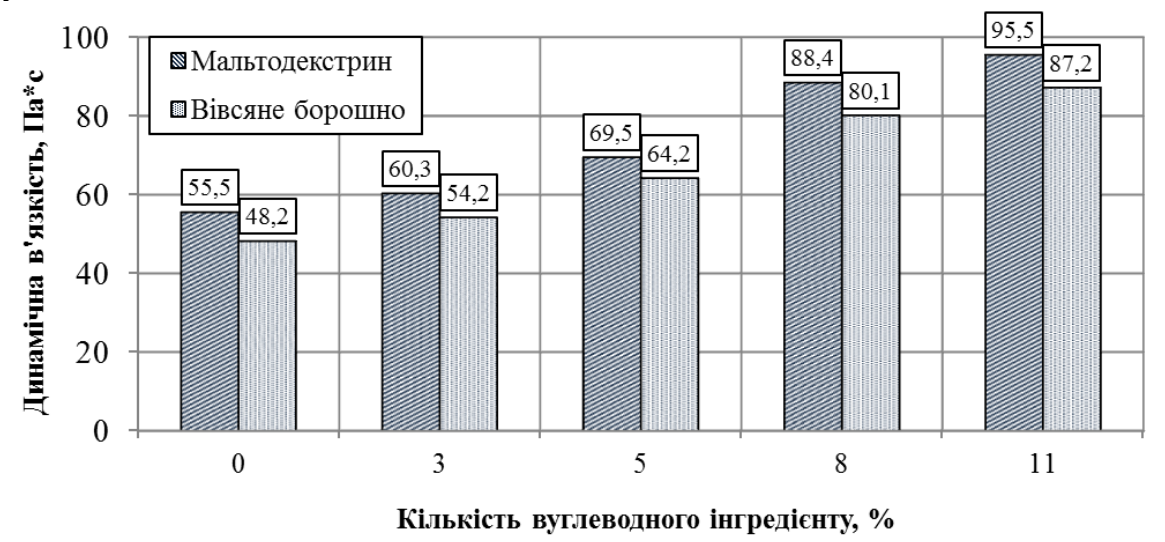

Рис. 1. Вплив виду та кількості вуглеводного компоненту в молочній суміші на показник динамічної в'язкості

Результати дослідження впливу кількості вуглеводного компоненту на показник динамічної в'язкості молочної суміші показують лінійну залежність. Чим більша кількість вуглеводів, тим вищий показник в'язкості. В зразках 3 кількістю мальтодекстрину $11 \%$ спостерігається надмірно густа консистенція та показник динамічної в'язкості складає 95,5 Па·с. В модельних зразках суміші з додаванням такої ж кількості вівсяного борошна вищевказаний показник складає 87,2 Па·с. В обох зразках спостерігається густа, слабко текуча консистенція, тому такий склад суміші недоцільно застосовувати для формування кінцевої рецептури напою для спортсменів. У зразках з додаванням вівсяного борошна був присутній присмак даного інгредієнту. В разі його використання необхідно додатково додавати до рецептури напою підсолоджувачі та ароматизатори. Внесення мальтодекстрину в кількості 3...5\%, не дозволяє досягти заданого вмісту вуглеводів, хоча вже забезпечує в'язко-текучу консистенцію молочної суміші. Отже, для подальших досліджень обрано кількість мальтодекстрину $8 \%$. Крім цього, виконується рекомендоване обмеження за кількістю вуглеводів у напоях для спортсменів в середньому $10 \ldots 12 \% з$ урахуванням вмісту лактози в молочній основі 4,0..4,5\%.

Як основний жировий наповнювач для збагачення продукту поліненасиченими жирними кислотами було обрано соєву олію. Даний продукт містить у своєму складі поліненасичені жирні кислоти, що ви- значає його як компонент, що забезпечує функціональні властивості для профілактики артритів, підтримки і захисту суглобів при підвищених фізичних навантаженнях. Доза внесення соєвої олії визначена 3 розрахунку забезпечення в продукті масової частки жиру, рівної 3,2 \%, та у розрахунку забезпечення жирами організм спортсмена близько $10 \%$ від добової потреби. Для надання стійкої емульсії до складу напою потрібно ввести емульгуючий компонент. Для цього використано традиційний інгредієнт в молочножирових продуктах - лецитин, який виконує роль не тільки емульгатора, а і є функціональним компонентом.

Для визначення кількості внесення лецитину та вплив на консистенцію готового продукту були проведені дослідження, спрямовані на визначення стійкості емульсії. Вихідні дані - вуглеводно-білкова молочна основа 3 додаванням 3,2 \% олії від загальної маси продукту. Залежність стійкості емульсії від кількості лецитину, \%: 2,5; 3,0; 3,5; 4,0; 4,5; при постійній масі всіх інших рецептурних компонентів (масова частка мальтодекстрину - 8 \%, КСБ-УФ - 4,5 \%) показано на рис. 2.

3 рис. 2 видно, що стійкість емульсії з додаванням 0,4\% лецитину сягає $94 \%$, а наступні зразки майже не показують динаміку зростання показника стійкості емульсії. 3 отриманих даних можна зробити висновок, що доцільно вносити 0,4 \% лецитину до вуглеводнобілкової молочної суміші. 


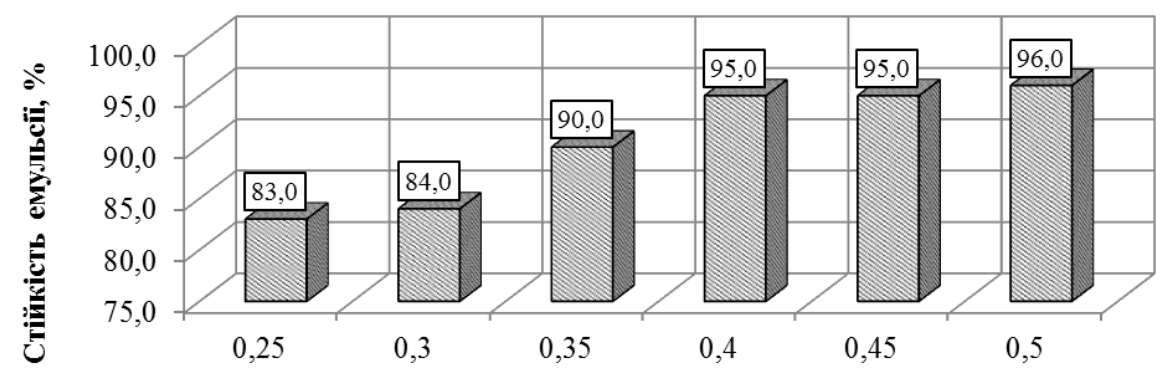

Кількість лецитину, \%

Рис. 2. Залежність стійкості емульсії вуглеводно-білкової молочної суміші від кількості лецитину

До речовин, що регулюють і активують реакції обміну, які при виконанні певних фізичних вправ протікають $з$ ускладненням, зачисляють ряд вітамінів. До складу продукту як вітамінно-мінеральну добавку введений полівітамінний премікс виробництва фірми BIOTECH USA NUTRITION "Multivitamin One A Day". Премікс містить 12 основних необхідних організму вітамінів та 10 мінеральних речовин в суміші 3 молочним цукром. Додатково до складу рецептури введено креатин моногідрат, який є стандартним компонентом сумішей для спортивного харчування. 3 урахуванням попередніх досліджень було уточнено рецептуру напою молочно-сироваткового для спортсменів, яка наведена в табл. 1.

\section{Таблиця 1}

Рецептура молочного напою для спортсменів, кг на 1000 кг готового продукту

\begin{tabular}{lc}
\hline \multicolumn{1}{c}{ Компоненти } & Маса, кг \\
\hline Молоко знежирене з м. ч. ж. 0,05 \% & 818,00 \\
Концентрат сироватковий білковий & 45,00 \\
“КСБ -УФ- 65” & 80,00 \\
Мальтодекстрин & 32,00 \\
Олія соєва & 4,00 \\
Емульгатор лецитин & 0,40 \\
Сухий екстракт левзеї сафлоровидної & 10,00 \\
Креатину моногідрат & 0,75 \\
Вітамінно-мінеральний премікс & 0,01 \\
Ароматизатор “Ваніль” & 1000,00 \\
Всього & \\
\hline
\end{tabular}

Таблиця 2

Задоволення добової потреби в харчових нутрієнтах за рахунок споживання порції продукту

\begin{tabular}{|c|c|c|c|}
\hline Нутрієнти & $\begin{array}{c}\text { Норма споживання для спортсменів сило- } \\
\text { вих видів спорту на добу }\end{array}$ & $\begin{array}{l}\text { Вміст в порції } \\
\text { напою, } 500 \text { г }\end{array}$ & $\begin{array}{c}\text { Задоволення добової } \\
\text { потреби, \% }\end{array}$ \\
\hline Білки, г & 232,00 & 55,42 & 23,90 \\
\hline Жири, г & 160,00 & 32,00 & 20,00 \\
\hline Вуглеводи, г & 944,00 & 116,81 & 12,40 \\
\hline \multicolumn{4}{|c|}{ Мінеральні речовини } \\
\hline $\mathrm{Ca}, \Gamma$ & 1,70 & 0,12 & 7,05 \\
\hline $\mathrm{P}, \Gamma$ & 2,10 & 0,11 & 87,50 \\
\hline $\mathrm{Fe}, \mathrm{M \Gamma}$ & 33,00 & 17,00 & 51,50 \\
\hline $\mathrm{Mg}, \Gamma$ & 0,60 & 0,01 & 1,70 \\
\hline \multicolumn{4}{|c|}{ Вітаміни } \\
\hline $\mathrm{C}, \mathrm{M \Gamma}$ & 180,00 & 120,00 & 66,70 \\
\hline $\mathrm{B}_{1}, \mathrm{M \Gamma}$ & 3,40 & 3,00 & 88,20 \\
\hline $\mathrm{B}_{2}, \mathrm{M \Gamma}$ & 4,30 & 3,00 & 93,02 \\
\hline $\mathrm{B}_{3}, \mathrm{M \Gamma}$ & 18,00 & 3,00 & 16,70 \\
\hline $\mathrm{B}_{6}, \mathrm{M \Gamma}$ & 7,00 & 3,00 & 42,90 \\
\hline В9, мг & 450,00 & 400,00 & 88,90 \\
\hline $\mathrm{B}_{12,}$, мкг & 6,00 & 5,00 & 83,30 \\
\hline $\mathrm{A}, \mathrm{M \Gamma}$ & 3,00 & 1,65 & 55,00 \\
\hline $\mathrm{E}, \mathrm{M \Gamma}$ & 25,00 & 20,00 & 80,00 \\
\hline
\end{tabular}

Виконано розрахунок харчової та енергетичної цінності розробленого напою і проведена оцінка задоволення добової потреби в мінеральних речовинах і вітамінах при вживанні напою в кількості 500 г на добу (табл. 2).

На підставі розробки виявлено, що нутрієнти однієї порції напою покривають добову потребу в необхідних поживних речовинах більше ніж на $10 \%$.

\section{Висновки}

В статті показано розроблення технології молочних напоїв для спортсменів, які займаються силовими видами спорту, 3 додаванням сироваткових білків молока. Наведено розрахунок добової кількості необхідних макронутрієнтів. Встановлено раціональну кількість та вид вуглеводного компонента, кількість емульгатора лецитину для забезпечення стійкості емульсії готового продукту в напої. Наведено склад 
рецептури продукту. Виконано розрахунок харчової та енергетичної цінності розробленого напою і проведена оцінка задоволення добової потреби в мінеральних речовинах і вітамінах при вживанні напою в кількості 500 г (1 порція).

\section{References}

Babich, O. O., Milent'eva, I. S., Ivanova, S. A., Pavsky, V. A., Kashirskikh, E. V., \& Yang, Y. (2017). The potential of pine nut as a component of sport nutrition. Foods and Raw materials, 5(2), 170-177. doi: 10.21603/2308-4057-2017-2-170-177.

Badau, D., Talaghir, L. G., Rus, V. \& Badau, A. (2018). The impact of the needs and roles of nutrition counselling in Sport. Human. Sport. Medicine, 18(2), 88-96. doi: $10.14529 / \mathrm{hsm} 180208$.

Bentleyab, M. R. N., Mitchell, N., \& Backhouse, S. H. (2020). Sports nutrition interventions: A systematic review of behavioural strategies used to promote dietary behaviour change in athletes, Appetite, 150, 104645, doi: 10.1016/j.appet.2020.104645.

Kalinina, I. V., Potoroko, I. Yu., Nenasheva, A. V., Velyamov, M. T., \& Bagale, U. (2018). Prospects for the Application of Taxifolin Based Nanoemulsions as a Part of Sport Nutrition Products. Human. Sport. Medicine, 18(4), 100-107. doi: 10.14529/hsm190114.

Latkov, N. Ju., Vekovcev, A. A., Nikitjuk, D. B., \& Poznjakovskij, V. M. (2018). Specializirovannyj produkt sportivnogo pitanija antioksidantnoj napravlennosti. Chelovek. Sport. Medicina, 18, 125134. doi: 10.14529/hsm18s18 (in Russian).

Rudavs'ka, G. B., Tishhenko, E. V., \& Pritul's'ka, N. V. (2002). Naukovi pidhody ta praktychni aspekty optymizacii asortymentu produktiv special'nogo pryyznachennja: Monografija. Kyiv (in Ukrainian).

Sorrenti, V., Caudullo, G., Lucignano, F., Fortinguerra, S., Zusso, M., Giusti, P., \& Buriani, A. (2019). Chapter Eighteen Personalized sports nutrition: Role of nutrients in athletic performance. Sports, Exercise, and Nutritional Genomics. Current Status and Future Directions, 2019, 411-431. doi: 10.1016/B978-0-12816193-7.00018-X.

Trofimov, I. E. (2016). Issledovanie i razrabotka tehnologii belkovo-uglevodnogo kislomolochnogo produkta dlja specializirovannogo pitanija. Vestnik OmGAU, 1(21), 14-19 (in Russian).

Zabodalova, L. A., Suchkova, E. P., Petrov, D. A., \& Krytchenkov, A. S. (2019). Razrabotka kompleksnikh kyslomolochnikh napytkov dlia sportyvnoho pytanyia. Chast 1. Vestnyk MAKH, 2, 55-61 doi: 10.17586/1606-4313-2019-18-2-55-61 (in Russian).

Zaharova, L. M., Pushmina, I. N., \& Pushmina, V. V. (2019). Kislomolochnyj produkt dlja sportivnogo pitanija. Chelovek. Sport. Medicina, 1, 26-29. doi: 10.14529/hsm19s117 (in Russian). 